\title{
MJN THE ANALYSIS OF THE PSYCHOLOGICAL HEALTH STATUS OF SENIOR CITIZENS FROM NURSING HOMES IN LUOYANG, A THIRD LINE CITY OF CHINA
}

\author{
Huang Yang \\ Student counsellor, Luoyang Institute of Science and Technology, P R of China \\ Corresponding Author's Email: maryhuang72@163.com
}

\begin{abstract}
Objective: This study aims to investigate the psychological status of old pensioners who live in aged care facilities in Luoyang; and meanwhile, analyzing factors related those older adults. Methods: Totally 250 older people from 10 nursing homes in the urban area of Luoyang were investigated by random sampling method. A questionnaire-based survey with Self-rating Anxiety Scale (SAS) and Self-rating Depression Scale (SDS) was conducted to elderly participants. We also conducted the structured interview for some residents. Results: The age, monthly income, the number of chronic diseases that they suffered from and self-care ability were influential factors of SAS score in elderly participants. The age the number of chronic diseases that they suffered from and self-care ability were influential factors of SDS score in the elderly participants. Conclusion: The psychological health status of the elderly is closely related to their age, number of chronic disease that they suffered from and self-care ability.
\end{abstract}

Keywords: Nursing homes, Older residents, Psychological health, Self-care ability, Care requirements, Physical health, Chronic diseases

\section{INTRODUCTION}

The world has witnessed China's dramatic economic growth and social development since 1949. However, due to the long-term implementation of 'onechild' policy and extending people's life expectancy, the phenomenon of aging population in China has greatly accelerated (Feng et. al., 2012). Zhang et. al. (2017) emphasize that by 2050, the older generation in China will increase to 483 million and the aging proportion will go up to $34.1 \%$. Even worse, it was reported by World Health Organization (2016) that about $15 \%$ of adults aged 60 and above suffer from mental disorder, like anxiety, depression and so on.

It is generally acknowledged that the phenomenon of aging population not only poses a big challenge on pension industry but also increases huge social burden. As a consequence, in the long run, the development of pension institutions seems to be more important and necessary. On the one hand, these facilities are responsible for alleviating the part of social pension pressure. On the other hand, these institutions urgently need to find suitable strategies to guarantee the pleasant later life of older citizens.
This study focuses on the local senior residents from the aged care institutions in Luoyang, a third line city of China. We take ways of face-to-face interviews and questionnaires to know about their psychological health status. The paper analyzes the related factors of affecting the older generation under the social institution pension mode; and meanwhile, put forward the relevant recommendations for the current care models.

\section{METHODOLOGY}

\section{Study Design and Participants}

This survey was conducted between January 2019 and April 2019 in Luoyang city, which is located in the middle of China. Luoyang is an ancient city, which is famous for peony growing in the world. In addition, Longmen grottoes, a world heritage site, is another tourist attraction in Luoyang. The number of population in Luoyang reached over 680 million by 2018. Currently, there are 105 nursing homes distributed in urban and suburb of Luoyang.

The method of random sampling was applied to 250 senior citizens from 10 nursing homes in the urban and they were surveyed by questionnaires. Among them, 
there are five public nursing homes and five private aged care homes. We chose aged over 60 years, awareness, no communication barrier, no serious vision or hearing barrier as the research objects. Furthermore, we had structured interview for some residents.

Data were collected by questionnaire survey. Written informed consent was obtained from all participants, and this study was approved by the Ethics Committee of the School of Public Health, Luoyang Institute of Science and Technology.

\section{Research Tools}

Anxiety self-rating scales (SAS) and Self-rating depression scale (SDS) were used. Likert 1 4 was used in SAS scale and it contained a total of 20 items, using forward or reverse scoring. What's more, the score value is converted into standard score and the result is according to Chinese Module. SAS standard score is 50 points, among them 50 59 were classified as mild anxiety, 60 69 were classified as moderate anxiety and over 69 is classified as severe anxiety. Likert was used for SDS scale and grades 1 to 4 were scored according to the Chinese standard. As a result of the model, the standard score is 53 points. Clearly, if a standard score is over 53, it may indicate depression.

\section{Survey Method}

We take the method of questionnaire survey. Before survey, the investigators were given a unified training on the contents of the questionnaire. The participant would complete this questionnaire by himself if he is able to. If not, we will provide assistants with helping the elderly fill in the questionnaire in order to ensure the authenticity and validity of the samples. We issued 250 questionnaires and got 250 questionnaires back. The recovery rate of questionnaires was $100.00 \%$, eliminating the missing and unqualified questionnaires, and valid questionnaires occupied $92.4 \%$ (231 out of 250 ).

\section{RESULTS}

Anxiety and Depression Scores of the Elderly in Nursing Institutions

The SAS scale for the elderly in nursing institutions is generally divided into $(45.03 \pm 8.76)$, SDS scale is divided into $(54.01 \pm 9.64)$ points. In general, the psychological status of 231 older adults is good.

Table 1: Univariate Analysis of SAS Scale for Elderly in Nursing Institutions

\begin{tabular}{|c|c|c|c|c|}
\hline Items & & $n$ & $\mathbf{x} \pm \mathbf{S}$ & $p$ \\
\hline Gender & $\begin{array}{c}\text { Male } \\
\text { Female }\end{array}$ & $\begin{array}{c}135 \\
96\end{array}$ & $\begin{array}{l}44.14 \pm 7.72 \\
45.02 \pm 8.15\end{array}$ & 0.428 \\
\hline Ages & $\begin{array}{c}60-70 \\
70-80 \\
\text { Over } 80 \\
\end{array}$ & $\begin{array}{l}98 \\
81 \\
52 \\
\end{array}$ & $\begin{array}{l}45.10 \pm 8.02 \\
43.54 \pm 7.05 \\
44.84 \pm 8.50 \\
\end{array}$ & 0.027 \\
\hline Marital Status & $\begin{array}{c}\text { Unmarried } \\
\text { Married } \\
\text { Divorced } \\
\text { Death of a Spouse } \\
\end{array}$ & $\begin{array}{c}1 \\
187 \\
23 \\
20 \\
\end{array}$ & $\begin{array}{c}43.63 \\
44.80 \pm 8.04 \\
44.94 \pm 7.82 \\
45.14 \pm 7.02 \\
\end{array}$ & 0.735 \\
\hline Education Background & $\begin{array}{c}\text { Junior High School Degree } \\
\text { High School Degree } \\
\text { College Degree or Over }\end{array}$ & $\begin{array}{c}105 \\
116 \\
10\end{array}$ & $\begin{array}{l}43.94 \pm 7.56 \\
44.64 \pm 7.52 \\
45.14 \pm 7.02\end{array}$ & 0.893 \\
\hline Living Situation & $\begin{array}{l}\text { Living Alone } \\
\text { Living with Spouse } \\
\text { Living with Children }\end{array}$ & $\begin{array}{c}58 \\
168 \\
5 \\
\end{array}$ & $\begin{array}{l}46.04 \pm 7.02 \\
43.84 \pm 7.45 \\
44.64 \pm 8.02 \\
\end{array}$ & 0.694 \\
\hline Source of Livelihood & $\begin{array}{c}\text { Savings } \\
\text { Pension } \\
\text { Wages } \\
\text { Government Subsidies }\end{array}$ & $\begin{array}{c}57 \\
89 \\
83 \\
2\end{array}$ & $\begin{array}{l}41.94 \pm 5.42 \\
43.74 \pm 6.16 \\
40.98 \pm 3.82 \\
50.01 \pm 3.02 \\
\end{array}$ & 0.864 \\
\hline Monthly Income/RMB & $\begin{array}{c}\text { Below } 1000 \\
1000-2000 \\
\text { Over } 2000\end{array}$ & $\begin{array}{c}97 \\
102 \\
32\end{array}$ & $\begin{array}{l}43.64 \pm 5.10 \\
46.54 \pm 5.62 \\
43.17 \pm 6.02\end{array}$ & 0.000 \\
\hline $\begin{array}{c}\text { Combined Chronic } \\
\text { Diseases }\end{array}$ & $\begin{array}{l}\text { With One } \\
\text { With Two } \\
\text { Over Two } \\
\end{array}$ & $\begin{array}{l}63 \\
79 \\
89 \\
\end{array}$ & $\begin{array}{l}40.85 \pm 4.10 \\
43.67 \pm 5.12 \\
47.74 \pm 6.01 \\
\end{array}$ & 0.000 \\
\hline $\begin{array}{c}\text { Ability of } \\
\text { Independence }\end{array}$ & $\begin{array}{l}\text { Complete Independence } \\
\text { Partial Dependence } \\
\text { Complete Dependence }\end{array}$ & $\begin{array}{c}71 \\
148 \\
12\end{array}$ & $\begin{array}{l}40.54 \pm 4.02 \\
43.94 \pm 7.12 \\
51.64 \pm 2.05\end{array}$ & 0.019 \\
\hline
\end{tabular}


The Analysis of the Single Factor Influencing the SAS Scale Score of the Elderly in Nursing Institutions

The factors, such as age, monthly income, chronic diseases and self-care abilities, influence the SAS scale score of the elderly in nursing institutions. In addition, age over 80 years old and average monthly income level had been found to be suffering from a variety of diseases. The elderly with chronic diseases and poor self-care abilities scored higher on the SAS scale.

Table 2: Univariate Analysis of SDS Scale for Elderly in Nursing Institutions

\begin{tabular}{|c|c|c|c|c|}
\hline Items & & $n$ & $\mathbf{x} \pm \mathbf{s}$ & $p$ \\
\hline Gender & $\begin{array}{c}\text { Male } \\
\text { Female }\end{array}$ & $\begin{array}{c}135 \\
96\end{array}$ & $54.21 \pm 7.02 \quad 55.32 \pm 8.05$ & 0.687 \\
\hline Ages & $\begin{array}{c}60-70 \\
70-80 \\
\text { Over } 80\end{array}$ & $\begin{array}{l}98 \\
81 \\
52\end{array}$ & $\begin{array}{l}57.14 \pm 6.12 \\
54.84 \pm 7.15 \\
55.68 \pm 7.50\end{array}$ & 0.039 \\
\hline Marital Status & $\begin{array}{c}\text { Unmarried } \\
\text { Married } \\
\text { Divorced } \\
\text { Death of a Spouse }\end{array}$ & $\begin{array}{c}1 \\
187 \\
23 \\
20\end{array}$ & $\begin{array}{c}50.73 \\
53.70 \pm 8.01 \\
51.94 \pm 6.82 \\
54.50 \pm 7.62\end{array}$ & 0.789 \\
\hline Education Background & $\begin{array}{c}\text { Junior High School Degree } \\
\text { High School Degree } \\
\text { College Degree or Over }\end{array}$ & $\begin{array}{c}105 \\
116 \\
10\end{array}$ & $\begin{array}{l}53.94 \pm 6.50 \\
54.64 \pm 7.52 \\
58.14 \pm 4.02\end{array}$ & 0.296 \\
\hline Living Situation & $\begin{array}{c}\text { Living Alone } \\
\text { Living with Spouse } \\
\text { Living with Children }\end{array}$ & $\begin{array}{c}58 \\
168 \\
5\end{array}$ & $\begin{array}{l}56.03 \pm 5.02 \\
53.24 \pm 5.40 \\
54.64 \pm 6.02\end{array}$ & 0.314 \\
\hline Source of Livelihood & $\begin{array}{c}\text { Savings } \\
\text { Pension } \\
\text { Wages } \\
\text { Government Subsidies }\end{array}$ & $\begin{array}{c}57 \\
89 \\
83 \\
2\end{array}$ & $\begin{array}{l}51.94 \pm 4.72 \\
54.74 \pm 5.26 \\
52.98 \pm 4.62 \\
53.01 \pm 4.12\end{array}$ & 0.614 \\
\hline Monthly Income/RMB & $\begin{array}{c}\text { Below } 1000 \\
1000-2000 \\
\text { Over } 2000\end{array}$ & $\begin{array}{c}97 \\
102 \\
32\end{array}$ & $\begin{array}{l}52.64 \pm 4.20 \\
56.54 \pm 5.52 \\
53.17 \pm 7.02\end{array}$ & 0.200 \\
\hline $\begin{array}{c}\text { Combined Chronic } \\
\text { Diseases }\end{array}$ & $\begin{array}{l}\text { With One } \\
\text { With Two } \\
\text { Over Two }\end{array}$ & $\begin{array}{l}63 \\
79 \\
89\end{array}$ & $\begin{array}{l}50.85 \pm 4.50 \\
53.67 \pm 5.32 \\
57.74 \pm 5.41\end{array}$ & 0.000 \\
\hline $\begin{array}{c}\text { Ability of } \\
\text { Independence }\end{array}$ & $\begin{array}{l}\text { Complete Independence } \\
\text { Partial Dependence } \\
\text { Complete Dependence }\end{array}$ & $\begin{array}{c}71 \\
148 \\
12\end{array}$ & $\begin{array}{l}49.54 \pm 4.12 \\
53.94 \pm 6.32 \\
60.60 \pm 2.05\end{array}$ & 0.009 \\
\hline
\end{tabular}

The Analysis of the Single Factor Influencing the SDS Scale Score of the Elderly in Nursing Institutions

The factors, such as age, chronic disease and selfcare ability affect SDS scale score of the elderly in nursing institutions. Furthermore, considering the elderly SDS scale score factor, age over 80 years old, suffering from a variety of diseases and having poor selfcare abilities scored higher on the SDS scale.

\section{DISCUSSION}

The results of analysis of 231 elderly people in nursing homes showed that the changes of old citizens' psychological state are closely related to their ages.
Different age group of older pensioners may result in various scores for anxiety and depression, especially age over 80 years old people. Specifically, due to the decrease in their bodies' functions, the increase in their loneliness, and worrying more about their later years, they are more likely to suffer from high scores of depression and anxiety in this age group.

The age between 60 and 70 group scored higher than the age between 71 and 80 group. Tomek-Roksandic et. al. (2017) believed the reason for this is that the former group may have just left their work career as well as familiar living environment and thus, they seemed not to adapt to current life style well. All in all, we should call 
on more nursing homes to pay more attention to old adults' psychological health as well as to build more communication platform in order to improve their senses of wellbeing. For instance, we can utilize different strategies, such as health education, musical relaxation, psychological aids and instruction and entertainment, to alleviate older residents' the level of anxiety and depression.

The outcomes of this research also illustrate that whether having chronic diseases or not having farreaching influences on the psychological health of the elderly, there are $74.5 \%$ of the elderly with chronic diseases, and among them the elderly of at least two chronic diseases occupying 40.3\%. Zhang et. al. (2017) demonstrated that the majority of the older generation may have less knowledge regarding the chronic diseases and even feel confused between their unhealthy lifestyle and chronic illnesses. Consequently, Vancampfort et. al. (2017) suggested that improving the mental health of the elderly, helping them develop a good lifestyle, actively treating their chronic diseases, and adjusting their negative emotions caused by chronic diseases may lead to their physical and psychological wellbeing.

From the results of this research, it is obvious that there are $70.7 \%$ of the elderly living completely independent or partially dependent on the assistance of staff, $29.3 \%$ of the elderly completely relying on care service. Park et. al. (2007) state that when we look after the older generation, we should maintain their maximizing functional ability by doing various daily activities, prevent the occurrence of acute and chronic illnesses, and promote the quality of life. Miyawaki et. al. (2017) indicated that old adults' negative emotions are closely associated with the sense of self-control. In other words, physical independence plays a vital role in the mental health of the elderly. Therefore, this may require health care workers to focus more on the older clients' spiritual needs by their careful observation, passionate service attitudes and loving heart.

Last but not least, we can also see clearly from this study that monthly income is also an influential factor that affects older adults' emotions. The elderly with incomes less than $1000 \mathrm{RMB}$ and more than $2000 \mathrm{RMB}$ may have lower level of anxiety. This is because senior citizens with high monthly incomes can choose private nursing institutions to get better care services, while older residents with low monthly incomes can select public nursing homes to enjoy the retirement life. As a result, these two groups have lower level of anxiety compared with other groups.

\section{CONCLUSION}

To sum up, China has entered an aging society, the traditional family care model has already not met the urgent needs of majority of older adults as well as their families. To adapt to the current situation of aging society, in China, community endowment will become the main stream of the endowment model. In order to achieve this goal, the government, the bodies and individuals should get together to ensure adequate material life for the elderly; and meanwhile, we should pay more attention to their spiritual life and improve the quality of old age life. Only in this way, can we promote the comprehensive development of the physical and mental health of the elderly in the future.

\section{REFERENCES}

Feng, Z., Liu, C., Guan, X. \& Mor, V. (2012). China's rapidly aging population creates policy challenges in shaping a viable long-term care system. Health Affairs, 31(12), pp 2764-2773.

Miyawaki T., Kumamoto K., Shimoda K., Tozato F. \& Iwaya T. (2017). Relationship among motor function, ADL disability, and psychological concerns in elderly people with locomotive disorders. Journal Orthopaedic Science, 22(2), pp 339-344.

Park M. \& Tang J.H. (2007). Evidence-Based Guideline Changing the Practice of Physical Restraint Use in Acute Care. Journal of Gerontological Nursing, 33(2), pp 9-16.

Tomek-Roksandic S, Popek I, Mrcela N.T., Šostar Z., Kolarić B., Narančić N.S., Rukavina A.S. \& Ljubičić M. (2017). Psychogeriatric diagnoses in old people's homes and negative health behaviour. Psychiatria Danubina, 29(3), pp 369-375. 
Vancampfort D., Koyanagi A., Hallgren M., Probst M. \& Stubbs B. (2017). The relationship between chronic physical conditions, multimorbidity and anxiety in the general population: A global perspective across 42 countries. General Hospital Psychiatry, 45, pp 1-6.

World Health Organization. (2017). Mental health and older adults. Retrieved from: https://www.who.int/newsroom/fact-sheets/detail/mental-health-of-older-adults

Zhang H., Gao T., Gao J., Kong Y., Hu Y., Wang R. \& Mei S. (2017). A comparative study of negative life events and depressive symptoms among healthy older adults and older adults with chronic disease. International Journal of Social Psychiatry, 63(8), pp 699-707. 